\title{
Land Use and Land-Cover Change at "W" Biosphere Reserve and Its Surroundings Areas in Benin Republic (West Africa)
}

\author{
Laurent Gbenato Houessou ${ }^{1}$, Oscar Teka ${ }^{1}$, Ismaïla Toko Imorou ${ }^{1,2}$, Anne Mette Lykke ${ }^{3} \&$ Brice Sinsin ${ }^{1}$ \\ ${ }^{1}$ Laboratory of Applied Ecology, Faculty of Agronomic Sciences, University of Abomey-Calavi, Cotonou, Benin \\ ${ }^{2}$ Department of Geography, Faculty of Letter, Arts and Human Sciences, University of Abomey-Calavi, Cotonou, \\ Benin \\ ${ }^{3}$ Department of Bioscience, Aarhus University, Vejlsøvej 25, DK-8600 Silkeborg, Denmark \\ Correspondence: Laurent Gbenato Houessou, Laboratory of Applied Ecology, Faculty of Agronomic Sciences, \\ University of Abomey-Calavi, Cotonou, Benin. Tel: 229-9648-5593. E-mail: houessoulaurent@gmail.com
}

Received: January 28, 2013 Accepted: March 3, 2013 Online Published: March 10, 2013

doi:10.5539/enrr.v3n2p87 URL: http://dx.doi.org/10.5539/enrr.v3n2p87

\begin{abstract}
Biosphere Reserves stand as the worldwide strategy of biological conservation. However, the current global land use change involves extensive loss of vegetation cover around the reserves and increase their vulnerability and their ecological isolation. The overall objective of this study was to assess the trends of land covers change inand outside the "W" Biosphere Reserve (WBR) in Benin as well as the driving forces of land cover change in order to provide tools for its sustainable management. For this purpose, two serial times of maps from Landsat images TM 1995 and ETM+ 2006 were used to assess the rates and trends of the different land cover units from 1995 to 2006. Socioeconomic surveys based on structured interviews were conducted with 240 households in 8 villages around the reserve. Land clearing, tree logging, settlement and grazing were frequently quoted by the households as main driver forces inducing land cover change around WBR. Probability transition matrices of land cover displayed high probabilities $(>0.6)$ in the southern part of WBR and moderate probabilities $(0.3$ to 0.5$)$ in the northern part of WBR for woodland and savanna vegetation to be changed into cropland outside the reserve showing the persistence of vegetation degradation around WBR in the coming years. Our study revealed the urgent necessity of the development of conservation action planning to stop the agricultural frontline progression toward the reserve.
\end{abstract}

Keywords: deforestation rate, land use and land cover change, probability transition matrices, temporal maps, $\mathrm{W}$ National Park

\section{Introduction}

In addition to biodiversity decline and climate change, land cover/land use change is considered as an important factor contributing to the current global change (Turner, 2002; Meyfroidt \& Lambin, 2003; Verburg \& Veldkamp, 2005; Lepers et al., 2005). Land cover results from a complex process and can be considered as the biophysical state of the earth's surface and immediate sub-surface (Turner et al., 1995), while land use refers to the conversion or transformation of the land cover into the desired human purposes which are associated with that cover, e.g. cropping, conservation, or settlement (Meyer \& Turner, 1994).

The issue of land-cover/land use change has taken place since human beings shifted from goods harvesting in wild into the production of its own goods to satisfy its daily requirements (Turner et al., 1990). Since then, natural vegetation was progressively converted into agriculture land for crop production, animal grazing and other land use types (Turner et al., 1990). Due to the rapid increasing of the population demography during the two last centuries and subsequent land requirement for farming and urbanization, important amount of forest was converted into anthropogenic area (Turner et al., 1990; Ouedraogo et al., 2010). The rhythm of degradation of primary ecosystems and declined of associated biodiversity was alarming during the two last centuries (Goudie, 2006). Recently, FAO (2010) estimated the worldwide forest cover lost for about 13 million hectares per year during the last decade 2000-2010 with a persistent high decreasing rate in sub-saharan Africa. Most primary ecosystems are thereof been fragmented and large habitats are partitioned into smaller (Fahrig, 2003).

Sequel to habitat lost and land cover conversion in degraded ecosystem, protected areas were established all over 
the world to serve as representative land of biodiversity preservation for current and future generation (Pimm et al., 2001; UNEP, 2003; IUCN, 2005). They were thought to be an effective strategy to prevent habitat destruction and ensure ecosystems protection within their borders (Bruner, Gullison, Rice, \& da Fonseca, 2001; Clerici et al., 2007). However, due to lack of land, protected areas were reported to be more or less eroded by surrounding forest dwellers through agricultural use, cattle herding and human settlements (Defries, Hansen, Turner, Reid \& Liu, 2007; Clerici et al., 2007; Flamenco-Sandovala, Ramos, \& Masera, 2007). Wittemyer, Elsen, Bean, Burton and Brashares (2008) observed an accelerated human population growth in Africa and Latin America around protected areas and claimed that protected areas represent an attractive pole for human settlement by providing access to increasingly scarce ecosystem services (e.g., NTFPs, bushmeat) and jobs deriving from the protected areas management. The rapid increase in trends of the agricultural frontline from the communal to the borders of protected areas is a great concern since this increase protected areas vulnerability through their ecological isolation (DeFries, Hansen, Newton, \& Hansen, 2005; Struhsaker, Struhsaker, \& Siex, 2005).

In Benin, previous studies have assessed the land cover change and demonstrated its impact on natural habitats conversion into degraded habitats. For instance Oloukoi, Mama and Agbo (2006) showed in the central part of the country a land cover regression of about $59.4 \%$ from 1978 to 1998 and highlighted a high rate of savannah, galleries forest, woodland conversion into cropland. Similar trends were also observed in the region of Wari-Maro (Orekan, 2007). From the latest study which was focused on the period ranging from 1991 to 2000, the author concluded that the region is under high vegetation cover loss with an annual deforestation rate of $8 \%$. However, no specific study has tackled so far the land cover/land use change around the biosphere reserve in Benin although this remain a great concern to sustainably design conservation strategies for protected area management (Clerici et al., 2007, Flamenco-Sandoval et al., 2007). Therefore, this study was carried out as a case study of land cover/land use change around a protected area at "W" Biosphere Reserve located in the uppermost northeast Benin. Since land use intensity differs around the reserve according to different cropping systems, two study sites with different land use intensity were selected to assess the land cover/land use change around the protected area. Specifically our study aims (i) to assess the perception of land use/land cover change by local residents around the reserve and (ii) to quantify land cover/land use change at the out-and inside of the reserve.

\section{Method}

\subsection{Study Area}

The study was conducted in Benin at the "W" National Park actually named "W" Biosphere Reserve since 2002 (WBR) $\left(11^{\circ} 26^{\prime}-12^{\circ} 26^{\prime} \mathrm{N} ; 2^{\circ} 17^{\prime}-3^{\circ} 05^{\prime} \mathrm{E}\right.$, Figure 1). It is part of the transboundary Biosphere Reserve over Benin, Niger and Burkina Faso. The WBR in Benin covers 563,280 ha representing 56\% of the transboundary Biosphere's total area. As most Biosphere Reserves, WBR core area i.e. the protected area is separate from the communal lands (agro-system) by a buffer zone of $5 \mathrm{~km}$ width around the protected area. The WBR belongs to the regional centre of sudanian endemism (White, 1983). Two zones were sampled for land use and land cover change analysis: the first zone in the northern part $\left(1105.4 \mathrm{~km}^{2}\right)$ and the second zone in the southern $\left(850.9 \mathrm{~km}^{2}\right)$.

The cropping system in the southern part is based on cash crop production (mainly cotton) while the northern part of the WBR is based on food crop (Table 1). 
Table 1. Characteristics of the sampled zones

\begin{tabular}{|c|c|c|c|}
\hline Characteristics & Zone 1 & & one 2 \\
\hline Location & Banikoara district $\left(10^{\circ} 94-11^{\circ} 68 \mathrm{~N} \& 1^{\circ} 99-2^{\circ} 90 \mathrm{E}\right)$ & $\begin{array}{r}\text { Karimama distr } \\
\& 2^{\circ} 28\end{array}$ & $\begin{array}{l}\text { trict }\left(11^{\circ} 4-12^{\circ} 4 \mathrm{~N}\right. \\
\left.8-3^{\circ} 28 \mathrm{E}\right)\end{array}$ \\
\hline Rainfall & $900-1100 \mathrm{~mm}$ & $600-9$ & $900 \mathrm{~mm}$ \\
\hline Temperature & $18-35^{\circ} \mathrm{C}$ & $17-$ & $-39^{\circ} \mathrm{C}$ \\
\hline Climate type & Sudanian & Sudano- & o-sahelian \\
\hline $\begin{array}{l}\text { Active } \\
\text { vegetation } \\
\text { period }\end{array}$ & 180 days (May to October) & 150 days (June & ne to September) \\
\hline Vegetation & $\begin{array}{l}\text { Woodland, various type of savannah, gallery forest, } \\
\text { fallows }\end{array}$ & $\begin{array}{r}\text { Woodland, v } \\
\text { savannah, galler }\end{array}$ & $\begin{array}{l}\text { various type of } \\
\text { ery forest, fallows }\end{array}$ \\
\hline Soils types & $\begin{array}{l}\text { Tropical ferruginous soil with concretions and on pure } \\
\text { crystalline rock, mineral and poorly evolved soil, } \\
\text { brown soils and clayed soils }\end{array}$ & $\begin{array}{r}\text { Ferruginou } \\
\text { concretions on } \\
\text { rock and c }\end{array}$ & $\begin{array}{l}\text { us type with } \\
\text { pure crystalline } \\
\text { clayed soils }\end{array}$ \\
\hline $\begin{array}{l}\text { Main ethnic } \\
\quad \text { group }\end{array}$ & Bariba and Peulh & $\begin{array}{r}\text { Dendi, Peulh, } \\
\text { Haoussa }\end{array}$ & $\begin{array}{l}\text {, Gourmantché, } \\
\text { a, Djerma }\end{array}$ \\
\hline $\begin{array}{l}\text { Cropping } \\
\text { system }\end{array}$ & $\begin{array}{c}\text { Mainly based on cotton crop and secondary on } \\
\text { sorghum, corn, yam, and cassava. } \\
\text { Livestock raising }\end{array}$ & $\begin{array}{r}\text { Mainly based on } \\
\text { and corn, y } \\
\text { Livestoc } \\
\text { Fishing repr } \\
\text { importan }\end{array}$ & $\begin{array}{l}\text { n sorghum, millet, } \\
\text { yam, cassava, } \\
\text { ck raising. } \\
\text { resent also an } \\
\text { int activity }\end{array}$ \\
\hline & $\begin{array}{l}-\quad \text { Surveyed village } \\
\text { Delimited area for } \\
\text { W Biosphere Rese } \\
200000\end{array}$ & limit & 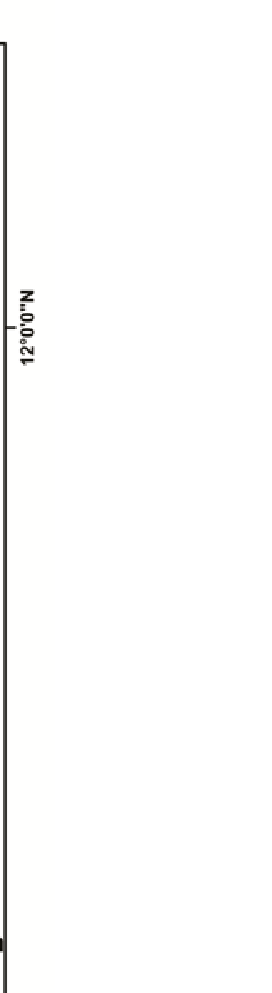 \\
\hline
\end{tabular}

Figure 1. Map of the study area showing the clipped areas in the northern and in the southern of the reserve for land use and land cover (LUCC) analysis 


\subsection{Data Collection}

Two types of data were collected:

\subsubsection{Socio-Economic Data}

A survey based on structured interviews was conducted in the southern part of the reserve in the villages of Sampéto, Kandérou, Nipouni and Founougo (district of Banikoara) and in the northern part of the reserve in the villages of Karimama, Kofonou, Karigui and Monsey (district of Karimama). The interviews were realized from March to June 2008 and from February to April 2009. A total of 240 household were randomly selected in the targeted villages i.e. 30 per villages. Apart from socio-demographic characteristics of the household (age of the household chief, household size, household active population size, household chief education level, ethnic group, gender, etc.), interviewees were asked the main following questions:

- Are you aware of land cover change in your village during the last ten years $(1=$ yes, $0=$ no $)$ ?

- Do you clear woody vegetation during the last five year for agriculture purpose $(1=\mathrm{yes}, 0=\mathrm{no})$ ?

- Do the soil fertility decrease or increase during the last five years ( $3=$ increase; $2=$ stable; $1=$ decrease)?

- What are the driving forces of land cover change?

\subsubsection{Cartographic Data: Land Use/Land Cover Map Acquisition}

The land use/land cover maps for the WBR and its surrounding areas were acquired at the "Centre National de Télédetection (CENATEL)". For this purpose, two serial times of maps i.e. land use/land cover maps from Landsat images TM 1995 and ETM+ 2006 were used. In ArcGIS 9.3 software, we clipped the acquired maps at the southern part of the reserve and at the northern part of the reserve. The clipped areas were selected in order to have part of the reserve in the clipped section and one other part outside the reserve (Figure 1). In the clipped maps we grouped the cover types: settlement, farm and fallow as farmland in order to avoid misinterpretation of data analysis since these three covers type appear sometimes indistinct.

\subsection{Data Analysis}

\subsubsection{Interview Data Analysis}

We estimated the level of awareness of land use/land cover change as the percentage of household giving the answers yes out of the total number of surveyed households. Frequency citation of perceived driving forces which induce land cover change was estimated as:

$$
F_{C}=100 \times N / L \text { with confidence interval }(\alpha=0.05)=1.96 \times 100\left[F_{C}\left(1-F_{C}\right) / L\right]^{1 / 2}
$$

where $\mathrm{N}$ is the number of households who quoted a given factor as inducing land cover change and $\mathrm{L}$ the total number of household. Chi-sq test was used to test whether there was association between household perception of factors inducing land cover change and age category of the household chief, main activities, ethnic group, level of education, and geographic location.

We used a logit instead of the probit model to assess the factors which significantly influenced the decision of household to clear land during the last five years since the logit model is more interpretable (Long, 1997; Hurlin, 2003). The model is defined as follow:

$$
\begin{gathered}
P_{i}=\operatorname{Prob}\left(Y_{i}=1 / x_{i}\right)=F\left(x_{i} \beta\right), i: 1, \ldots \ldots, N \\
F\left(x_{i} \beta\right)=\frac{e^{x_{i} \beta}}{1+e^{x_{i} \beta}}=\frac{1}{1+e^{-x_{i} \beta}}
\end{gathered}
$$

Where the function $F$ follows a standard logistic distribution and is expressed as:

$$
c_{i}=\frac{p_{i}}{1-p_{i}}=e^{x i \beta} \text { or } \ln \left(\frac{p i}{1-p i}\right)=\beta_{0}+\sum_{j=1}^{k} \beta_{j} X_{j i}
$$

Finally

Where $\beta_{0}$ is the constant and $\beta_{1}, \beta_{2}, \ldots \beta_{\mathrm{k}}$ are the coefficients of the independent variables $\mathrm{X}_{1 \mathrm{i}}, \mathrm{X}_{2 \mathrm{i}}, \ldots, \mathrm{X}_{\mathrm{ki}}$, and (pi/1-pi) is the odds. The model predicts the logit of the dependent variable (decision to clear land) based on the independent variables. The logit is the napierian logarithm of the ratio of the probability pi (realization of the event) and 1-pi (non-realization of the event). 
To implement the model, the investigated independent variables were: household population size (i.e. total number of persons in the household), household active population size (i.e. total number of persons with age ranging from 15 to 55 years old), age of the household chief, ethnic group, level of education, household main activities and, perceived soil fertility level. The following codification was used (Table 2).

Table 2. Description of the independent variables

\begin{tabular}{|c|c|c|c|}
\hline Variables & Codes & Nature & Explanation and modalities \\
\hline Ethnic group & ETHNIE & Nominal & $\begin{array}{c}1=\text { Bariba; } 2=\text { Gourmantché; } 3=\text { Dendi; } 4=\text { Haoussa, } \\
5=\text { Djerma; } 6=\text { Others }\end{array}$ \\
\hline Household population size & HOUPOP & Continue & Numerical Value \\
\hline $\begin{array}{l}\text { Household active } \\
\text { population size }\end{array}$ & ACTPOP & Continue & Numerical Value \\
\hline Age of the Household chief & AGE & Ordinal & $1=<30 ; 2=30-60 ; 3=>60$ \\
\hline Level of education & EDUCAT & Ordinal & $1=$ Illiterate $; 2=$ Primary school $3=$ Secondary school \\
\hline Household main activities & ACTIVIT & Nominal & $1=$ Agriculture $; 2=$ Breeding $; 3=$ Fishing \\
\hline Perceived soil fertility & FERTIL & Ordinal & $3=$ Increase $;=$ Stable $; 1=$ Decrease \\
\hline
\end{tabular}

The significance of the coefficient of the logistic regression was appreciated based on the chi-sq likelihood and Wald statistics. The global logit-model significance was assessed with 2-log likelihood and the level of fitness.

\subsubsection{Analysis and Quantification of Land Cover Change}

The deforestation rate ( $r$ ) was assessed inside and outside of the reserve both at the northern part and the southern part of this reserve based on formula proposed by Puyravaud (2003) as follow:

$$
\mathrm{r}=\frac{1}{t_{2}-t_{1}} \ln \frac{A_{2}}{A_{1}}
$$

Where ' $r$ ' is the deforestation rate (\% of vegetation cover lost/year); $A_{1}$ and $A_{2}$ represent the undegraded lands cover classes respectively for the periods 1995 and 2006. The undegraded land covers classes are represented here by Woodland, Gallery forest, Tree and Shrub savannah and $t_{2}-t_{1}$ is the interval in years during which change in land cover is being assessed.

\subsubsection{Land Cover Conversion Matrix}

Based on the information of land-cover classes from the two observed periods, cross-tabular comparison using the algorithm Intersect available in ArcGIS 9.3 were used to assess the differences in extent of each class and the conversion that took place between the two periods. Transition matrices were elaborated for the periods 1995 to 2006 with respect to the subset areas. We determined the transition matrix separately for inside and outside the protected area both in the northern part and southern part. Each matrix represents either the persistence area of each land cover category during the period 1995 to 2006, or the area which was converted to another land-cover category during the same period.

In addition to transition matrix, we determined the transition probability matrices. Values in the cells of the transition probability matrices represented the probabilities of conversion or persistence of each land use into another one. Probabilities values were computed following Oloukoui et al. (2006). The probability of one cell belonging to class $\mathbf{C}_{\mathbf{i}}$ during the initial year (1995) to be converted into class $\mathbf{C}_{\mathbf{j}}$ during the final year (2006) was calculated as:

$$
\mathbf{P}_{\mathrm{i}-\mathrm{j}}=\mathbf{A}_{\mathrm{Ci}-\mathrm{Cj}} / \mathbf{A}_{\mathbf{i}(\mathbf{1 9 9 5 )}}
$$

where $\mathbf{A}_{\mathbf{C i}-\mathrm{Cj}}$ was the area of the land cover class $\mathbf{C i}$ to $\mathbf{C j}$ from the year 1995 to 2006 and $\mathbf{A}_{\mathbf{i}(1995)}$ was the total area of the land cover class $\mathbf{C}_{\mathbf{i}}$ in the year 1995. 


\section{Results}

\subsection{Local Communities' Awareness Level of Land Covers Change}

More than $80.4 \%$ (95\% CI: [75.37-85.42\%]) of the respondents were aware of conversion of land cover change during the last ten year preceding the surveyed period i.e. from 1998-2008. About 87.5\% (95\% CI: [81.6 93.4\%]) and 73.3\% (95\% CI: [65.4-81.2\%]) of the household opined for change in land cover respectively in the southern and the northern part of the reserve. Regardless the region of the reserve, no difference were found in land cover change awareness with respect to the main activities (chi-sq=2.994; $\mathrm{P}=0.084$ ), level of education (chi-sq $=0.259 ; \mathrm{P}=0.879$ ), and ethnic group (chi-sq=6.726; $\mathrm{P}=0.151$ ) of the household chief. However the age of the household chief significantly affected its opinion about the land cover change awareness (chi-sq $=8.638 ; \mathrm{P}$ $=0.013$ ). Old chief opined for land cover change while young chief were not often aware of land cover change.

\subsection{Communities' Perception of Driving Forces Inducing Land Cover Change}

Overall, 82.5\% (95\% CI: [77.6-87.3\%]); 36.3\% (95\% CI: [30.1-42.3\%]); 27.4\% (95\% CI: [21.8-33.0\%]); $24.3 \%$ (95\% CI: [18.9-29.7\%]) of the household considered respectively land clearing for crop production, tree logging, settlement and grazing by livestock as factors inducing land cover change in their village (Figure 2). A significant difference was observed between household frequency citation of factors inducing land cover change between the southern and northern part of the reserve (chi-sq $=54.26 ; \mathrm{P}<0.00)$. It was noteworthy to underline that land clearing $(\mathrm{Fc}=36.3 \%)$ and tree logging $(\mathrm{Fc}=18.1 \%)$ were mostly quoted as factors inducing land cover change in the southern part of the reserve while land clearing $(48.4 \%)$ and livestock grazing $(\mathrm{Fc}=26.6 \%)$ in the northern part of the reserve.

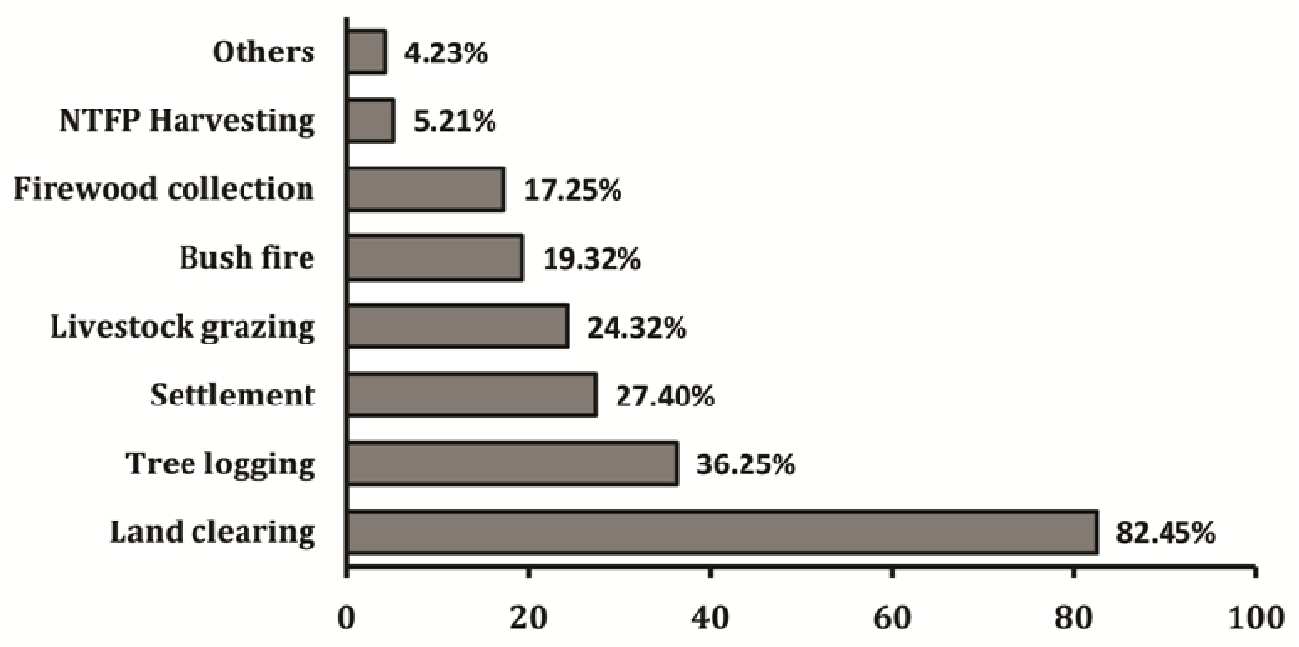

\section{Driving forces perceived as inducing LUCC by Household}

Figure 2. Factors perceived by respondents as driving force of land cover change around the WBR

\subsection{Factors Determining Land Clearing by Households around WBR}

The logit model estimation was globally significant (2log-likelihood $=53.27 ; \mathrm{R}^{2}$ of Cox \& Snell $=0.50 ; \mathrm{R}^{2}$ of Nagelkerke $=0.66)$ with a good prediction $\left(\mathrm{R}^{2}=63.30 \%\right)$. The coefficients were also globally significant (Test of Omnibus; Chi-sq $=41.28 ; \mathrm{P}<0.001$ ). The households' decision to clear vegetation i.e. to convert forest cover into agriculture land was significantly influenced by the household active population size and perceived soil fertility (Table 3). The coefficient was negative with the soil fertility suggesting that decline in soil fertility is conducive of higher probability of land clearing. Regarding, the household size and main active population, the coefficient was positive. This would indicate that decision of land clearing increases when the household size and active population size increased. As revealed by our investigation, traditionally in the southern part as well as in the northern part of the reserve, when the agriculturally active children (mainly boys) in the household reach their maturity (i.e. able to get married, about 20 years old), the chiefs of the household have to share part of the household lands with them or have to find new fields to be cleared for them. This results into: (i) partition of the primary cropland hold by the household for the new independent farmers (mature children of the household) 
and/or (ii) acquisition of new land for clearing by the new independent farmers.

Table 3. Factors determining land clearing decision by the household

\begin{tabular}{llll}
\hline Variables & Coefficient & Wald $\chi^{2}$ test & P-value \\
\hline Household population size & 0.012 & 0.005 & 0.943 \\
Household active population size & 1.16 & 6.92 & 0.009 \\
Household chief Age & 0.009 & 0.065 & 0.799 \\
Ethnic group & -0.149 & 0.026 & 0.872 \\
Level of education & 0.094 & 0.005 & 0.945 \\
Household main activities & 0.505 & 0.2 & 0.655 \\
Soil fertility & -0.325 & 5.263 & 0.017 \\
Constant & 4.638 & 7.311 & 0.007 \\
\hline
\end{tabular}

\section{Estimated statistics:}

$\mathrm{R}^{2}=63.3 \%$

Omnibus Test of significant coefficients: Chi-sq $=41.282 ; \mathrm{p}<0.001$

Test of Hosmer \& Lemeshow: Chi-sq $=23.655 ; \mathrm{dF}=7 ; \mathrm{p}=0.001$;

$-2 \log$-likelihood $=53.277 ; \mathrm{R}^{2}$ of Cox $\&$ Snell $=0.50 ; \mathrm{R}^{2}$ of Nagelkerke $=0.66$.

Global percentage of prediction $=63.3 \%$.

\subsection{Land Covers Change Dynamics in and outside the WBR from 1995 to 2006}

Land cover maps (Figure 3) showed that in 1995 tree and shrub savannah (28.20\%) followed by degraded savannah $(27.31 \%)$ were the most dominant land cover types in the subset region at the unprotected area in the south of the reserve (Table 4). In 2006, in the same area, farmland became the most dominant land cover type with $87.10 \%$ of the area at the expense of degraded savannah and tree and shrub savannah. In the inner of the reserve in 1995 (south), land covers maps displayed a high proportion of tree and shrub savannah $(54.15 \%)$ and of woodland $(30.35 \%)$. Till the year 2006, in that part of the reserve, tree and shrub savannah $(56.40 \%)$ and woodland (33.94\%) remained the most dominant land cover types.

As far as the northern part of the reserve was concerned, during the year 1995, farmland displayed high proportion $(44.59 \%)$ in the subset region of the unprotected area. In 2006, the situation was almost similar with high proportion of farmland (63.96\%) comparatively to the others land covers types. In the inner of the reserve at the northern part, tree and shrub savannah was the most dominant land cover types with $96.75 \%$ in proportion, the situation did not sensibly change in 2006 where tree and shrub savannah still remain the most abundant land cover type (97.03\%).

Table 4. Proportion of each land cover in percentage in 1995 and 2006

\begin{tabular}{|c|c|c|c|c|c|c|c|c|}
\hline \multirow[t]{2}{*}{ Land cover types } & \multicolumn{2}{|c|}{$\begin{array}{l}\text { Unprotected } \\
\text { area (South) }\end{array}$} & \multicolumn{2}{|c|}{$\begin{array}{l}\text { Protected } \\
\text { (South) }\end{array}$} & \multicolumn{2}{|c|}{$\begin{array}{l}\text { Unprotected } \\
\text { area (North) }\end{array}$} & \multicolumn{2}{|c|}{$\begin{array}{l}\text { Protected } \\
\text { (North) }\end{array}$} \\
\hline & 1995 & 2006 & 1995 & 2006 & 1995 & 2006 & 1995 & 2006 \\
\hline Farmland & 22.52 & 87.10 & 1.65 & 5.30 & 44.59 & 63.96 & 0.02 & 0.11 \\
\hline Woodland & 21.65 & 0.12 & 30.35 & 33.94 & 3.01 & 1.01 & 2.24 & 2.46 \\
\hline Gallery forest & 0.32 & 0.33 & 3.15 & 4.16 & 4.66 & 5.46 & 0.27 & 0.30 \\
\hline Degraded Savannah & 27.31 & 3.40 & 10.70 & 0.21 & 11.88 & 17.05 & 0.72 & 0.1 \\
\hline Tree+Shrub savannah & 28.20 & 9.05 & 54.15 & 56.40 & 32.96 & 11.07 & 96.75 & 97.03 \\
\hline Opened grassland & - & - & - & - & 2.8 & 1.45 & - & - \\
\hline
\end{tabular}




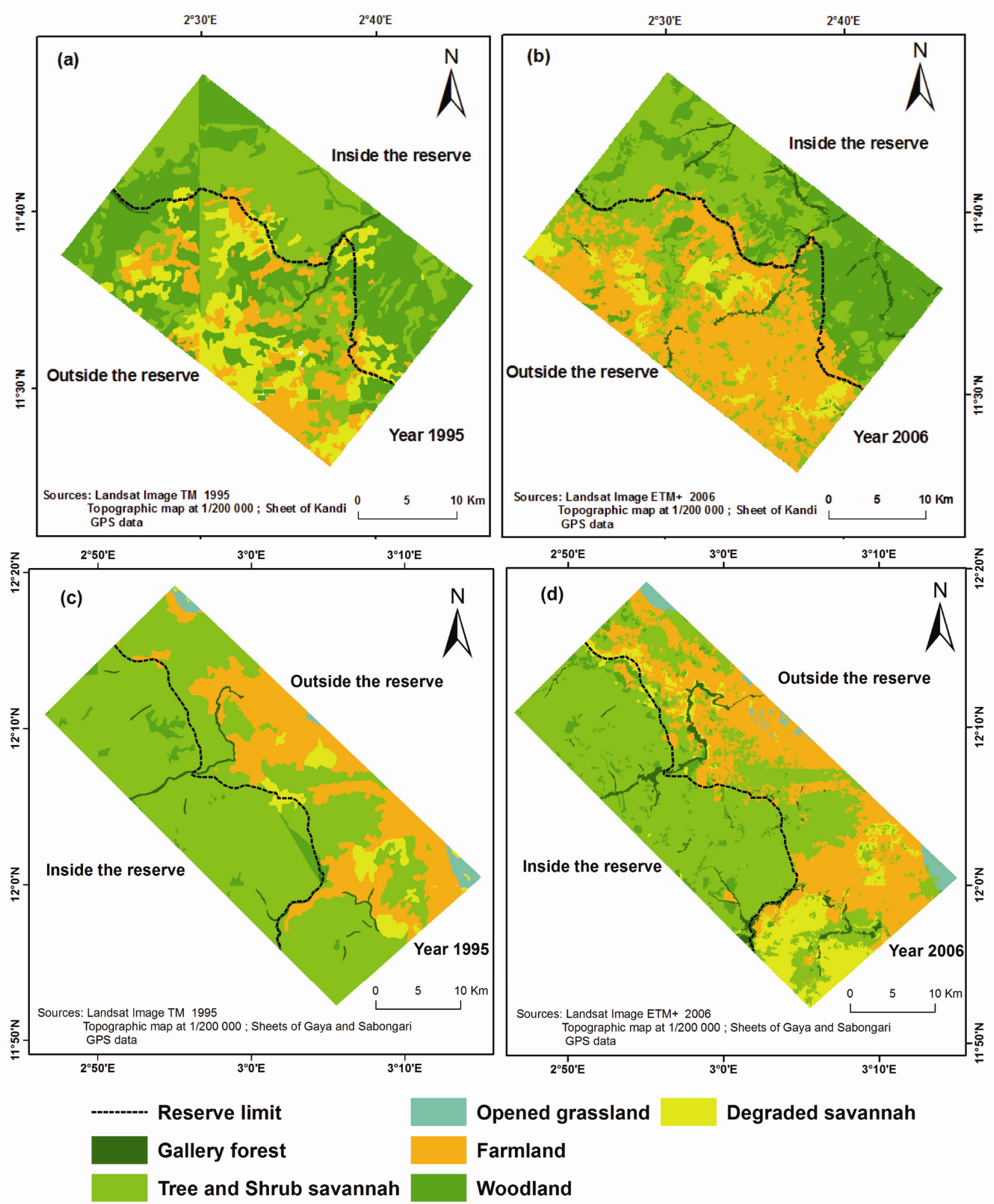

Figure 3. Land use/Land cover covers maps change from 1995 to 2006 in the south and north of WBR Legend

a- South of WBR in 1995, b- South of WBR in 2006.

c- North of WBR in 1995, d- North of WBR in 2006. 

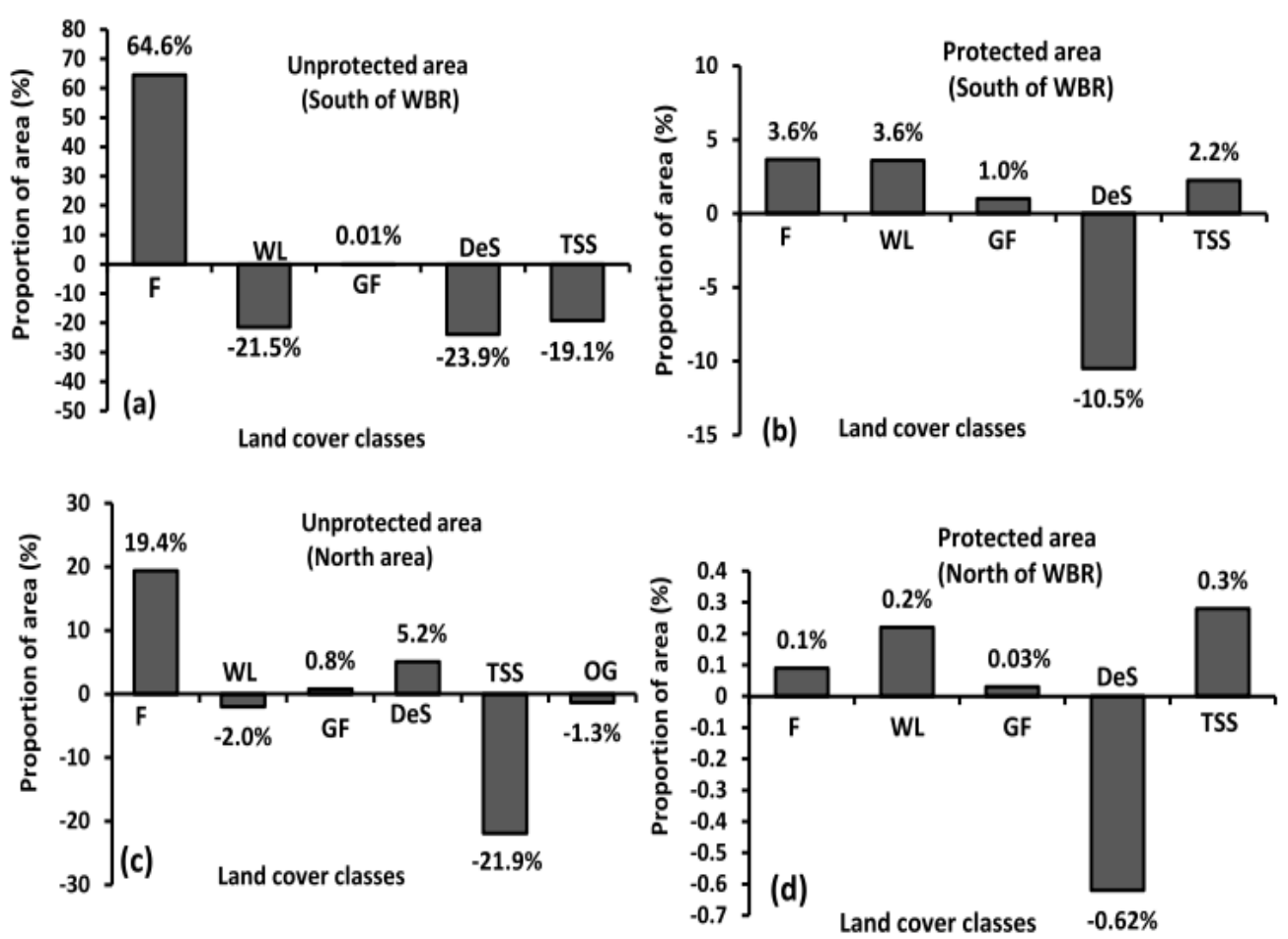

Figure 4. Land covers dynamics from 1995 to 2006 at WBR and surrounding areas

Legend: $\mathrm{F}=$ Farmland; $\mathrm{WL}=$ Woodland; $\mathrm{GF}=$ Gallery Forest; TSS $=$ Tree and Shrub Savannah, OG =Opened Grassland; DeS = Degraded Savannah

$\mathrm{a}=$ Land cover change in the South of WBR in the unprotected area from 1995 to 2006.

$\mathrm{b}=$ Land cover change in the South of WBR in the protected area from 1995 to 2006.

$\mathrm{c}=$ Land cover change in the North of WBR in the unprotected area from 1995 to 2006.

$d=$ Land cover change in the North of WBR in the protected area from 1995 to 2006.

Figure 4 displayed the land cover types dynamic from 1995 to 2006 . We observed that in the south of the WBR and in the unprotected area, gallery forest was almost stable $(0.01 \%)$ farmland increased for $64.6 \%$ while woodland, degraded savannah and tree/shrub savannah decreased in area respectively for $-21.5 \%$; $-23.9 \%$; and $-19.1 \%$ showing the conversion of land cover from woody vegetation to anthropogenic vegetation (Figure 4a). Meanwhile, in the north of WBR in the unprotected area, the same situation (i.e. conversion of forest cover to anthropogenic vegetation) was observed (Figure 4c). However, the rate of conversion into anthropogenic vegetation appeared as lower in the north. Farmland increased for about $64.6 \%$ in the south while in the north the farmland increased for $19.4 \%$.

The land cover dynamic in the protected area both in the southern part and northern part of the reserve showed an increase in the extension of tree/shrub savannah, woodland, gallery forest and farmland. Woodland, gallery forest, tree/shrub savannah and farmland increased respectively for $3.6 \%, 1.0 \%, 2.2 \%$ and $3.6 \%$ in the southern of the reserve and for $0.2 \%, 0.03 \%, 0.3 \%$ and $0.1 \%$ in the northern of the reserve (Figure $4 \mathrm{~b}$ and Figure $4 \mathrm{~d}$ ).

\subsection{Deforestation Rate}

The deforestation rate was higher (about 15.13\%) outside the reserve at the unprotected area in the south part of the reserve comparatively to the northern part of the reserve where the deforestation rate was about $7.63 \%$ (Figure 5). In contrast, it is noteworthy to remark a slight increase in vegetation cover inside the reserve in the south as well as in the north part. 


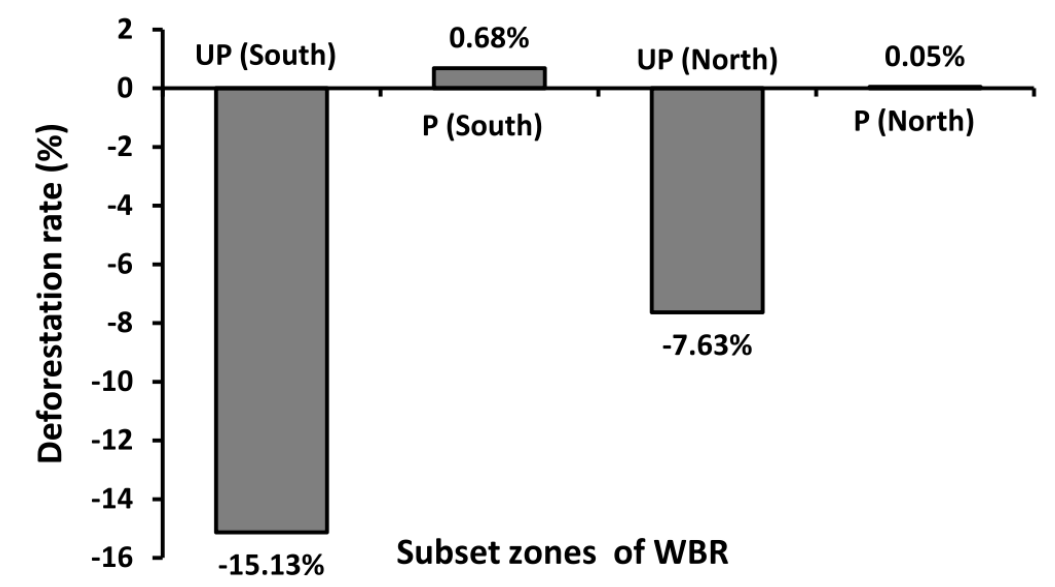

Figure 5. Deforestation rate outside and inside in the north and the south of WBR

Legend:

UP $($ south $)=$ Unprotected area in the south of the subset zones of WBR;

$\mathrm{P}($ south $)=$ Protected area in the south of the subset zones of WBR;

UP (north) $=$ Unprotected area in the north of the subset zones of WBR;

$\mathrm{P}($ north $)=$ Unprotected area in the north of the subset zones of WBR.

Table 5. Transition probability matrices of the land cover type from 1995 to 2006 inside and outside of the reserve at the northern and southern of the reserve

\begin{tabular}{|c|c|c|c|c|c|c|}
\hline & $\mathbf{F}$ & WL & GF & $\overline{\text { DeS }}$ & TSS & OG \\
\hline \multicolumn{7}{|c|}{ Unprotected area(South) } \\
\hline $\mathbf{F}$ & 0.9642 & 0 & 0.0002 & 0.0316 & 0.004 & - \\
\hline WL & 0.9061 & 0.0043 & 0.0008 & 0.0888 & 0 & - \\
\hline GF & 0.0119 & 0.0027 & 0.9854 & 0 & 0 & - \\
\hline DeS & 0.9718 & 0.0009 & 0 & 0.0272 & 0 & - \\
\hline TSS & 0.6706 & 0 & 0 & 0.0009 & 0.3286 & - \\
\hline \multicolumn{7}{|c|}{ Protected area (South) } \\
\hline $\mathbf{F}$ & 0.0896 & 0 & 0.001 & 0.0045 & 0.9049 & - \\
\hline WL & 0.0038 & 0.7494 & 0 & 0 & 0.2468 & - \\
\hline GF & 0.0011 & 0 & 0.9989 & 0 & 0 & - \\
\hline DeS & 0.0383 & 0.0148 & 0 & 0 & 0.9469 & - \\
\hline TSS & 0.0146 & 0.4865 & 0 & 0 & 0.4989 & - \\
\hline \multicolumn{7}{|c|}{ Unprotected area (North) } \\
\hline $\mathbf{F}$ & 0.9604 & 0 & 0.008 & 0 & 0.0209 & 0.0107 \\
\hline WL & 0.3647 & 0.0102 & 0.0447 & 0.0079 & 0.5716 & 0.0009 \\
\hline GF & 0.0366 & 0 & 0.9631 & 0 & 0 & 0.0003 \\
\hline DeS & 0.4743 & 0 & 0.0033 & 0.517 & 0.0054 & 0 \\
\hline TSS & 0.3707 & 0 & 0 & 0.3441 & 0.2849 & 0.0003 \\
\hline OG & 0.3579 & 0 & 0 & 0 & 0.3056 & 0.3365 \\
\hline \multicolumn{7}{|c|}{ Protected area (North) } \\
\hline $\mathbf{F}$ & 0 & 0.2657 & 0 & 0 & 0.7343 & - \\
\hline WL & 0 & 0.7651 & 0 & 0 & 0.2349 & - \\
\hline GF & 0.0577 & 0 & 0.9423 & 0 & 0 & - \\
\hline DeS & 0.0119 & 0 & 0.0003 & 0.1437 & 0.8442 & - \\
\hline TSS & 0.0009 & 0.0076 & 0 & 0 & 0.9914 & - \\
\hline
\end{tabular}

Legend

F = Farmland; $\mathrm{WL}=$ Woodland $; \mathrm{GF}=$ Gallery Forest; $\mathrm{DeS}=$ Degraded Savanna; TSS = Tree and Shrub Savanna. 


\section{Discussion}

\subsection{Community Perception of Land Cover/Land Use Change}

The study reported that the land cover change was largely perceived by local population around the reserve. This highlights the evidence of land conversion and land use change around the protected areas as showed previously by DeFries et al. (2007). Among socio-demographic factors which could likely influence population perception of land cover change, only respondent age has been found as significant. In fact, the perception of land use/land cover change required long time experience which elder persons dispose. This might explain the significant difference obtained with respect to the age which appears as significant factor for land use/land cover change (LUCC) perception (Lykke, Fog \& Madsen, 1999).

\subsection{Land Use/Land Cover Change Dynamic}

Regarding the perceived driving forces causing land cover change, $80 \%$ of the respondents opined land clearing for crop production. From our results it can be concluded that agriculture is the main driving force for land cover change in the region. This result is consistent with previous studies (Lambin, Geist, \& Lepers, 2003; Wood, Tappan, \& Hadj, 2004) which concluded that agriculture remains the principal factor inducing land cover change in sub-Saharan Africa. However the perceived driving forces could vary from a region to another. For instance, Arouna, Toko, Djogbénou and Sinsin (2011) found that charcoal production represented the main activity leading to land cover change in the centre of Benin while Lykke (2000) reported frequent intensive fires and declining rainfall as factors inducing vegetation change in a semi-arid region of Sine Saloum in Senegal.

The household active population size affected significantly the household decision to clear new land for agriculture. Indeed, the internal growth of the household population involves more persons to be supported by the household; so that more revenue and food production are required. As response to this requirement, farmers often decide to clear new field in order to overcome their household charge increasing. This is in accordance with the findings of Orekan (2007) and Ouedraogo et al. (2010) who concluded in their study at a strong correlation between the population growth and land degradation.

In addition to the active population size, soil fertility depletion affected significantly the household decision for land clearing in the region. This could be explained by the traditional cropping system consisting of slash and burn cultivation. After land clearing, farmers exploited the arable land for a period and when the soil fertility is decreasing, they moved to another place to clear. However, due to the rapid population growth and the increasing demand of land for agriculture purpose, most farmers complained nowadays that they have to stay for a long period in the same land since they cannot go over the limit of the reserve. While considering the growth of the household and the limit imposed by the reserve, it can be deduced in a near future that the problem of cropping land will be a great issue in the region as many farmers yet complained for land scarcity for clearing.

With respect to land cover dynamics, our findings showed the conversion of land cover from forest cover to anthropogenic vegetation made of farmland (fallow, field and agglomeration) in the communal land around the reserve both in the north and south. However, the land cover degradation during the study period appeared more much important in the south than in the north. As it was estimated the deforestation rate in the south was nearly twice of that observed in the north $(15.13 \%$ in the south vs $7.63 \%$ in the north). This could be explained by the type of crops produced in the two regions. In the south part of the reserve, cash crop (mainly cotton) is the most cultivated while, food crops (sorghum and maize) are the most practiced in the north. Cotton crop represents the top cash crops in Benin country and the government encourages it production by providing to the farmers technical support such as fertilizers, pesticides and tractors to improve their capacity. This national agricultural policy results in the increasing of cropland in the expense of forest cover as it was in the south of the reserve. Therefore incentive policies for improving crop production may result in the forest cover degradation as previously showed by Gray (2005) and Ouedraogo et al. (2010). The driving forces of land cover and land use change can be globally mapped in two groups (Figure 6). Direct factors such as socio-economic activities, population growth and natural ecological factors related to the ecosystem and the indirect factors related to the policy decision at local, national and regional level. Some policies decisions such as economic incentives price of a given crop could influence indirectly the pressure on land cover. This is the specific case of cotton crop in communal lands around the "W" biosphere reserve in Benin. Moreover, institutional factors, such as land tenure and legislation, can contribute in land use/land cover change (Reid et al., 2000). Hence, we concluded that factors inducing land cover change are as well of at local, national and international level. 


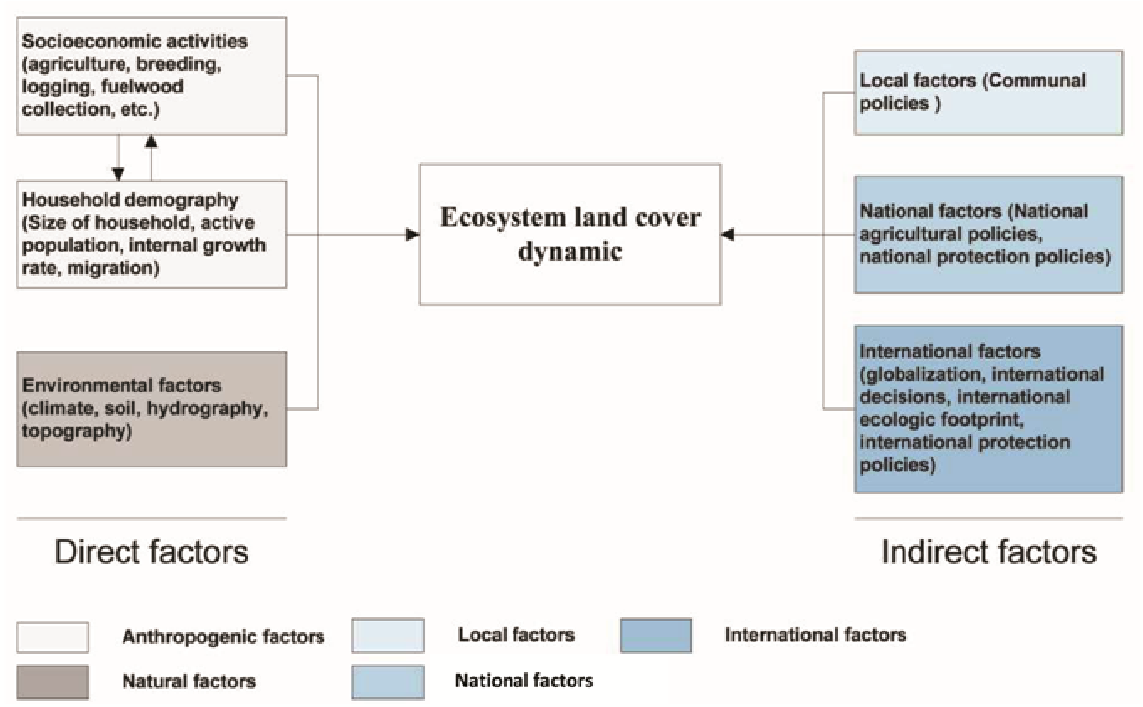

Figure 6. Driving forces to land cover change

\subsection{Land Use and Land Cover Transition Matrices}

As showed by the transition matrix, the probabilities of the different land cover units to be converted into farmland were higher outside the reserve. Thus, future scenarios of land cover change will result in a rapid conversion of the original vegetation outside the reserve into anthropogenic vegetation if the land use changes dynamic remain similar as it was observed between 1995 and 2006. This situation may involve the loss of biodiversity outside the reserve and increase anthropogenic pressures on the reserve since human being rely on diversity to improve their livelihood (Vodouhê, Coulibaly, Greene, \& Sinsin, 2009). The situation would be much of concern in the south than in the north since the probabilities of the different land cover unit's to be converted into farmland were higher in the south than in the north.

\subsection{Accuracy of Cover Maps}

In savannah vegetation, the satellite images data processing and interpretation is often limited by the absence of time series imagery data during the same or consecutive year to accurately establish land cover maps (Ruelland et al., 2010). Indeed, some pixels are sometimes misinterpreted due to the absence of time series imagery data and relevant field data on the period where the satellite images have been taken to well control each pixel interpretation. In the same time, farmland seemed to slightly increase inside the reserve for that period. In this study, in contrast to our expectation, gallery forests were almost stable from 1995 to 2006 outside the reserve although anthropogenic pressure is high outside this reserve. In the same time, farmland seemed to slightly increase inside the reserve. A possible argumentation must be linked to the misinterpretation of the different pixels during satellite image processing and analysis. Time series satellite images data analysis during the same year could help to fix this issue. Unfortunetaley, such data are lacking in our context. Nonetheless, data showed high deforestation rate and rapid land cover conversion into anthropogenic vegetation around the reserve. This in turn, highlights the important pressure and the ecological isolation of the reserve as demonstrated early by Clerici et al. (2007). Park managers should therefore implement conservation strategies outside the reserve to control the progression of agriculture frontline towards the reserve. This might be possible through the improvement of soil fertility based on sustainable agroforestry practises.

\section{Conclusion}

This study provides knowledge of land cover/land use change in and around the "W" biosphere reserve in Benin. Results showed a rapid degradation of land cover outside the reserve during our study period while within the reserve the deforestation rate is lower. This highlights the necessity to define best management practices in order to stabilize the agricultural frontline progression toward the park. Practices such as agricultural intensification and soil fertility improvement could help increasing crop productivity so that the farmers don't need to expand their field in the intention to increase their production. As shown in this study active population growth results in the land clearing for agriculture purpose. It appears then that population growth could be viewed as pressure indicator for the "W" biosphere reserve conservation. Temporal maps analysis allowed detecting change 
occurring in land cover during the period 1995 and 2006. However, future scenarios based on annualized transition matrices appear as more precise for understanding LUCC change dynamics, and will enable to assess the land cover change in long period. Therefore further studies based on the simulation of land cover change in and around the reserve are required.

\section{Acknowledgments}

This research was funded by the SUN project (Sustainable Use of Natural vegetation in West Africa) (EU FP6 INCO-dev 031685). We are grateful to Belarmain Fandohan for comments and corrections provided on the early version on this manuscript. We thank Oloukoï Joseph for sharing ideas with us during the course of this manuscript writing.

\section{References}

Arouna, O., Toko, I., Djogbénou, C. P., \& Sinsin, B. (2011). Comparative analysis of local populations' perceptions of socioconomic determinants of vegetation degradation in sudano-guinean area in Benin (West Africa). International Journal of Biodiversity and Conservation, 3, 327-337.

Bruner, A. G., Gullison, R. E., Rice, R. E., \& da Fonseca, G. A. B. (2001). Effectiveness of Parks in Protecting Tropical Biodiversity. Science, 291, 125-128. http://dx.doi.org/10.1126/science.291.5501.125

Clerici, N., Bodini, A., Eva, H., Gregoire, J. M., Dulieu, D., \& Paolini, C. (2007). Increased isolation of two Biosphere Reserves and surrounding protected areas (WAP ecological complex, West Africa). Journal for Nature Conservation, 15, 26-40. http://dx.doi.org/10.1016/j.jnc.2006.08.003

DeFries, R., Hansen, A., Newton, A. C., \& Hansen, M. C. (2005). Increasing isolation of protected areas in tropical forests over the past twenty years. Ecological Application, 15, 19-26. http://dx.doi.org/10.1890/03-5258.

Defries, R., Hansen, A., Turner, B. L., Reid, R., \& Liu, J. (2007). Land use change around protected areas: management to balance human needs and ecological function. Ecological Application, 17, 1031-1038. http://dx.doi.org/10.1890/05-1111.

Fahrig, L. (2003). Effects of habitat fragmentation on biodiversity. Annual Review of Ecology, Evolution, and Systematics, 34, 487-515. http://dx.doi.org/10.1146/annurev.ecolsys.34.011802.132419

FAO. (2010). Global Forest Resources Assessment 2010: Final Report. FAO FORESTRY PAPER 163. Rome.

Flamenco-Sandovala, A., Ramos, M. M., \& Masera, O. R. (2007). Assessing implications of land-use and land-cover change dynamics for conservation of a highly diverse tropical rain forest. Biological Conservation, 138, 131-145. http://dx.doi.org/10.1016/j.biocon.2007.04.022.

Goudie, S. A. (2006). The human impact on the natural environment: $6^{\text {th }}$ edition. Blackwell Publishing, USA.

Gray, L. C. (2005). What kind of intensification? Agricultural practice, soil fertility and socioeconomic differentiation in rural Burkina Faso. The Geographical Journal, 171, 70-82. http://dx.doi.org/10.1111/j.1475-4959.2005.00150.x

Hurlin, C. (2003). Econométrie des Variables Qualitatives Polycopié de Cours. Chap. 1. Retrieved from http://frederik.ducrozet.free.fr/econometrics/qualitatives/Qualitatif_Chapitre1.pdf

IUCN. (2005). Benefits beyond boundaries. Proceedings of the Vth IUCN world parks congress. The World Conservation Union, Durban.

Lambin, E. F., Geist, H. J., \& Lepers, E. (2003). Dynamics of land-use and land-cover change in tropical regions. Annual Review of Environment and Resources, 28, 205-241. http://dx.doi.org/10.1146/annurev.energy.28.050302.105459

Lepers, E., Lambin, E. F., Janetos, A. C., Defries, R., Achard, F., Ramankutty, N., \& Scholes, R. J. (2005). A Synthesis of Information on Rapid Land-cover Change for the Period 1981-2000. BioScience, 55, 115-124. http://dx.doi.org/10.1641/0006-3568(2005)055[0115:ASOIOR]2.0.CO;2

Long, J. S. (1997). Regression models for categorical and limited variable dependent variables. Advances quantitative techniques in the social sciences, Vol. 7. SAGE Publications, Inc. London-NewDelhi.

Lykke, A. M. (2000). Local perceptions of vegetation change and priorities for conservation of woodysavanna vegetation in Senegal. Journal of Environmental Management, 59, 107-120. http://dx.doi.org/10.1006/jema.2000.0336

Lykke, A. M., Fog, B., \& Madsen, J. E. (1999). Woody vegetation changes in the Sahel of Burkina Faso assessed 
by means of local knowledge, aerial photos, and botanical investigations. Danish Journal of Geography, Special Issue 2, 57-68.

Meyer, W. B., \& Turner II, B. L. (1994). Change in Land use and Land cover: Global perspective Driving force. Cambrige University Press.

Meyfroidt, P., \& Lambin, E. F. (2003). Global Forest Transition: Prospects for an End to Deforestation. Annual $\begin{array}{lllll}\text { Review of } & \text { Environment }\end{array}$ http://dx.doi.org/10.1146/annurev-environ-090710-143732

Oloukoi, J., Mama, V. J., \& Agbo, F. B. (2006). Modélisation de la dynamique de l'occupation des terres dans le département des collines au Bénin. Télédétection, 6, 305-323.

Orekan, V. O. A. (2007). Implementation of the local land-use and land-cover change model CLUE-s for Central Benin by using socio-economic and remote sensing data. $\mathrm{PhD}$ Dissertation. University of Bonn.

Ouedraogo, I., Tigabu, M., Savadogo, P., Compaore, H., Oden, P. C., \& Ouadba, J. M. (2010). Land cover change and its relation with population dynamics in Burkina faso, West Africa. Land Degradation \& Development, 21, 453-462. http://dx.doi.org/10.1002/ldr.981

Pimm, S. L., Ayres, M., Balmford, A., Branch, G., Brandon, K., Brooks, ... Wilcove, D. (2001). Can we defy Nature's end? Science, 233, 2207-2208. http://dx.doi.org/10.1126/science.1061626

Puyravaud, J. P. (2003). Standardizing the calculation of the annual of deforestation. Forest Ecology and Management, 177, 593-596. http://dx.doi.org/10.1016/S0378-1127(02)00335-3.

Reid, R. S., Kruska, R. L., Muthui, N., Taye, A., Wotton, S., Wilson, C. J., \& Mulatu, W. (2000). Land-use and land-cover dynamics in response to changes in climatic, biological and socio-political forces: The case of southwestern Ethiopia. Landscape Ecology, 15, 339-355. http://dx.doi.org/10.1023/A:1008177712995

Ruelland, D., Levavasseur, F., \& Tribotté, A. (2010). Patterns and dynamics of land-cover changes since the 1960s over three experimental areas in Mali. International Journal of Applied Earth Observation and Geoinformation, 12S, S11-S17. http://dx.doi.org/10.1016/j.jag.2009.10.006

Struhsaker, T. T., Struhsaker, P. J., \& Siex, K. S. (2005). Conserving Africa's rain forests: Problems in protected areas and possible solutions. Biological Conservation, 123, 45-54. http://dx.doi.org/10.1016/j.biocon.2004.10.007.

Turner II, B. L. (2002). Toward integrated land-change science: Advances in 1.5 decades of sustained international research on land-use and land-cover change. In W. Steffen, J. Jäger, D. J. Carson \& C. Bradhsaw, (Eds.), Challenges of a Changing Earth (pp. 21-26). Berlin: Springer. http://dx.doi.org/10.1007/978-3-642-19016-2_3

Turner II, B. L., Clark, W. C., Kates, R. W., Richards, J. F., Mathews, J. T., \& Meyer, W. B. (1990). The Earth As Transformed by Human Action: Global and Regional Changes in the Biosphere Over the Past 300 Years. UK: Cambridge University Press.

Turner II, B. L., Skole, D., Sanderson, S., Fischer, G., Fresco, L., \& Leemans, R. (1995). Land-Use and Land-Cover Change; Science/Research Plan. IGBP Report no. 35; HDP Report No. 7.

UNEP. (2003). World database on protected areas. IUCN-WCPA/UNEP-WCMC, Washington DC. Available at http://www.unep-wcmc.org/wdpa/(Assessed on June 2012).

Verburg, P. H., \& Veldkamp, A. (2005). Introduction to the Special Issue on Spatial modeling to explore land use dynamics. International Journal of Geographical Information Science, 19, 99-102. http://dx.doi.org/10.1080/13658810410001713362

Vodouhê, F. G., Coulibaly, O., Greene, C., \& Sinsin, B. (2009). Estimating the Local Value of Non-Timber Forest Products to Pendjari Biosphere Reserve Dwellers in Benin. Economic Botany, 63, 397-412. http://dx.doi.org/10.1007/s12231-009-9102-7

White, F. (1983). Vegetation of Africa: a descriptive memoir to accompany the UNESCO AETFAT UNSO vegetation map of Africa. UNESCO, Paris.

Wittemyer, G., Elsen, P., Bean, W. T., Burton, A. C. O., \& Brashares, J. S. (2008). Accelerated Human Population Growth at Protected Area Edges. Science, 321, 123-126. http://dx.doi.org/10.1126/science.1158900

Wood, E. C., Tappan, G. G., \& Hadj, A. (2004). Understanding the drivers of agricultural land use change in 
south-central Senegal. Journal of Arid Environments, 59, 565-582. http://dx.doi.org/10.1016/j.jaridenv.2004.03.022.

Appendix 1. Land cover unit matrix of transition from 1995 to 2006 inside and outside the reserve at the northern and southern part of the reserve

\begin{tabular}{|c|c|c|c|c|c|c|c|}
\hline & $\mathbf{F}$ & WL & GF & DeS & TSS & OG & Area 1995 \\
\hline \multicolumn{8}{|c|}{ Unprotected area(South) } \\
\hline $\mathbf{F}$ & 10353.98 & 0 & 2.48 & 339.42 & 42.53 & - & 10738.41 \\
\hline WL & 9353.52 & 43.97 & 8.2 & 917.12 & 0 & - & 10322.82 \\
\hline GF & 1.79 & 0.41 & 148.08 & 0 & 0 & - & 150.28 \\
\hline DeS & 12652.82 & 12.12 & 0 & 354.63 & 0 & - & 13019.58 \\
\hline TSS & 9015.18 & 0 & 0 & 11.53 & 4416.95 & - & 13443.67 \\
\hline Area 2006 & 41377.29 & 56.5 & 158.76 & 1622.7 & 4459.48 & & 47674.73 \\
\hline \multicolumn{8}{|c|}{ Protected area (South) } \\
\hline $\mathbf{F}$ & 177.84 & 0 & 1.9 & 8.98 & 1795.7 & - & 1984.41 \\
\hline WL & 43.08 & 8509.91 & 0 & 0 & 2802.33 & - & 11355.32 \\
\hline GF & 1.28 & 0 & 1176.74 & 0 & 0 & - & 1178.02 \\
\hline DeS & 100.97 & 39.14 & 0.12 & 0 & 2498.26 & - & 2638.49 \\
\hline TSS & 294.92 & 9856.53 & 0 & 0 & 10108.23 & - & 20259.68 \\
\hline Area 2006 & 618.09 & 18405.58 & 1178.76 & 8.98 & 17204.52 & & 37415.93 \\
\hline \multicolumn{8}{|c|}{ Unprotected area (North) } \\
\hline $\mathbf{F}$ & 23875.53 & 0 & 198.1 & 0 & 520.64 & 265.26 & 24859.53 \\
\hline WL & 196.49 & 5.51 & 24.11 & 4.25 & 308.02 & 0.46 & 538.84 \\
\hline GF & 106.54 & 0 & 2804.4 & 0 & 0 & 0.8 & 2911.74 \\
\hline DeS & 3006.74 & 0 & 21.07 & 3277.34 & 34.44 & 0 & 6339.59 \\
\hline TSS & 6381.32 & 0 & 0 & 5923.48 & 4904.07 & 5.22 & 17214.09 \\
\hline OG & 536.37 & 0 & 0 & 0 & 458.01 & 504.28 & 1498.66 \\
\hline Area 2006 & 34102.99 & 5.51 & 3047.68 & 9205.07 & 6225.18 & 776.02 & 53362.45 \\
\hline \multicolumn{8}{|c|}{ Protected area (North) } \\
\hline $\mathbf{F}$ & 0 & 3.78 & 0 & 0 & 10.45 & - & 14.24 \\
\hline WL & 0 & 978.12 & 0 & 0 & 300.24 & - & 1278.35 \\
\hline GF & 8.84 & 0 & 144.26 & 0 & 0 & - & 153.09 \\
\hline DeS & 4.88 & 0 & 0.11 & 59.12 & 347.34 & - & 411.46 \\
\hline TSS & 51.6 & 422.39 & 0 & 0 & 54861.27 & - & 55335.27 \\
\hline Area 2006 & 65.32 & 1404.29 & 144.37 & 59.12 & 55519.3 & & 57192.4 \\
\hline
\end{tabular}

Legend: $\overline{F=F a r m l a n d ; ~} \mathrm{WL}=$ Woodland; GF =Gallery Forest; DeS =Degraded Savannah; TSS =Tree and Shrub Savannah. 